Institute of

Public Finance
NEWSLETTER

AN OCCASIONAL PUBLICATION OF THE INSTITUTE OF PUBLIC FINANCE

\title{
Excise duties system in Groatia closer to the European system
}

\author{
DANIJELA KULIŠ Institute of Public Finance
}

February saw the announcement of a new Law on Excises (ZOT, in Croatian Zakon o trošarinama), the aim of which is to incorporate European excise institutes into the legislation of the Republic of Croatia and harmonise Croatian excise duties with the minimum amounts of excise rates prescribed in EU directives. The Law came into force on March 2, with the exception of certain provisions that will be applied from the day of accession to the EU. The first part of the Law on Excises contains the fundamental provisions of the excise system, and the second relates to the taxation of harmonised excise products, while the third contains offence, procedural and transitional/final provisions.

The Law introduces the electronic Excise Movement and Control System (EMCS) into the territory of the Republic of Croatia as of March I, 20I3; as of the day of accession to the EU, it will be established between the Republic of Croatia and other EU member states. The system enables electronic exchange of information between authorised economic operators and competent customs and tax bodies in member states, the aim being to monitor the movements of excise goods in the system of suspension of excise duties. ${ }^{\text {I }}$ EMCS replaces the accompanying excise document with an electronic administrative document.

\begin{abstract}
Importing excise goods for personal use
If a natural person imports and carries in person excise goods for personal and not for commercial purposes, goods that have already been released for consumption in another member state, under certain conditions no liability to pay excise duties is incurred.

Imported excise goods are deemed not to be intended for commercial purposes if the quantity does not exceed: 800 cigarettes; 400 cigarillos; 200 cigars; I kilogram of pipe tobacco; Io litres of spirits; 20 litres of unfinished products; 90 litres of wine, including at most 60 litres of sparkling wine; Ioo litres of beer. A liability to pay excise duties is incurred every time energy products are imported except for the carriage of motor fuel in the standard fuel tanks of motor vehicles or in appropriate portable canisters for reserve fuel up to io litres.
\end{abstract}

Below, the taxation of alcohol and alcoholic beverages, tobacco products, energy products and electricity is presented. The survey covers the current taxation system, changes that will occur at the time of EU accession and the harmonisations that have to be conducted in the following years.

\footnotetext{
${ }^{\mathrm{I}}$ The suspension of excise payment system is applied to the receipt, production, processing, warehousing and conducting other actions with excise goods and the dispatching of excise goods in which the liability for the payment of excise duties is suspended, which are not covered by the customs suspension system.
} 
Although minimum rates and taxable products are prescribed in the harmonised system of the EU, there are in fact considerable differences among the countries. For the purpose of providing an outline picture, the minimal prescribed and the actual rates applied in some EU countries and in the Republic of Croatia are displayed.

\section{EXGISE DUTIES ON ALCOHOL AND ALCOHOLIG BEVERAGES}

The amount of excise duty on alcohol and alcoholic beverages is not changed by the new Law. The current rates in the Republic of Croatia are at a rate higher than those minimally prescribed in the EU, and as far as European regulations are concerned need not be changed. On accession to the EU, the volume restrictions for commercial production outside the system of suspended payment of excise duties will be lifted. Producers who for commercial purposes produce alcohol, intermediate products and other beverages obtained by fermentation will be able to produce, i.e. to operate, outside the excise warehouses (Article 69) without depositing an instrument for security of excise duty payment, a facility not available to other producers of excisable goods.

In the production and processing of non-food products, an exempt user of excise goods will not pay excise duty on ethyl alcohol partially denatured by regulation preparations.

Table I

Rates of excise duty on alcohol and alcoholic beverages in the Republic of Croatia and the EU

\begin{tabular}{|c|c|c|c|}
\hline Excise product & Amount of excise in the RC & $\begin{array}{l}\text { Minimum excise duty } \\
\text { in the EU in euro }\end{array}$ & $\begin{array}{l}\text { Minimum excise duty } \\
\text { in the EU in kuna }\end{array}$ \\
\hline Beer & $\begin{array}{l}\text { 40 kuna for I\% actual alcoholic strength } \\
\text { in a hectolitre of finished product (hl } /{ }^{\circ} \text { alc) }\end{array}$ & $\begin{array}{l}\text { I.87€ hl/ }{ }^{\circ} \text { alc } \\
\text { o.748 } € \mathrm{hl} /{ }^{\circ} \text { Plato }\end{array}$ & $\begin{array}{l}\text { I3.89 kuna } \mathrm{hl} /{ }^{\circ} \text { alc } \\
5.55 \mathrm{kuna} \mathrm{hl} /{ }^{\circ} \mathrm{Plato}\end{array}$ \\
\hline Still wines & o kuna/hl of finished product & $\mathrm{o} €$ & o kuna/hl \\
\hline Sparkling wines & o kuna/hl of finished product & $o €$ & o kuna/hl \\
\hline $\begin{array}{l}\text { Other beverages } \\
\text { obtained from } \\
\text { fermentation, apart } \\
\text { from beers and wines }\end{array}$ & o kuna/hl of finished product & $o €$ & o kuna/hl \\
\hline Intermediate products & $\begin{array}{l}800 \mathrm{kuna} / \mathrm{hl} \text { of finished product } \\
\left(\geq \mathrm{I} 5 \% \mathrm{vol} /{ }^{\circ} \text { alc. }\right) \\
500 \mathrm{kuna} / \mathrm{hl} \text { of finished product } \\
\left(<\mathrm{I} 5 \% \mathrm{vol} /{ }^{\circ} \text { alc. }\right)\end{array}$ & $45 € / \mathrm{hl}$ & 334.I5 kuna/hl \\
\hline Ethyl alcohol & 5,300 kuna/hl or pure alcohol & $550 € / \mathrm{hl}$ of pure alcohol & 4,084.03 kuna/hl \\
\hline
\end{tabular}

Note: Converted according to the exchange rate of the ECB (OJ C 296, Oktober 2, 2OI2), I euro comes to 7.4255 kuna.

Source: European Commission (2013a); Zakon o trošarinama.

In the Republic of Croatia, every alcoholic product is taxed at a single rate, but in the EU for all categories of goods there are one or more standard and reduced rates. Standard rates can be higher or lower, for example, in the case of beer, where the rate relates on the malt concentration or the proportion of alcohol. Reduced rates depend on the produced quantity, and are applied to the beers of small independent breweries with an annual production of up to 200,000 $\mathrm{hl}$ (and the rate may not be lower than $50 \%$ of the standard rate). In the new Croatian Law (ZOT) no special rates for small breweries are provided. Beer with a smaller percentage of alcohol (up to 2.8\%) is taxed in the EU at reduced rates, in line with the share of alcohol. Although the rate of excise duty on beer in the Republic of Croatia (5.4 euro/hl) is measured by the share of alcohol almost $65 \%$ is higher than the minimum rate, only Lithuania, Latvia and Slovakia have rates lower than the Croatian (at 2.46, 3.13 and 3.59 euro/hl respectively). The rates of excise on beer measured according to proportion of alcohol are the highest in Finland, the UK and Sweden.

Graph I shows the amount of the rate on beer in EU countries according to the criteria of high malt concentration and proportion of alcohol ( $\mathrm{I} 2^{\circ} \mathrm{Plato}$ or $4.8 \%$ alcohol per hectolitre), which means that lower rates are applied in those countries. According to these criteria, the rate in the Republic of Croatia is the lowest, for beer is taxed only according to a single rate and according to only one criterion ( $\mathrm{I} \%$ volume proportion of actual alcohol in a hectolitre of finished product). 


\section{Graph I}

Rates of excise duties on beer in EU countries in 2012/2013, in euro

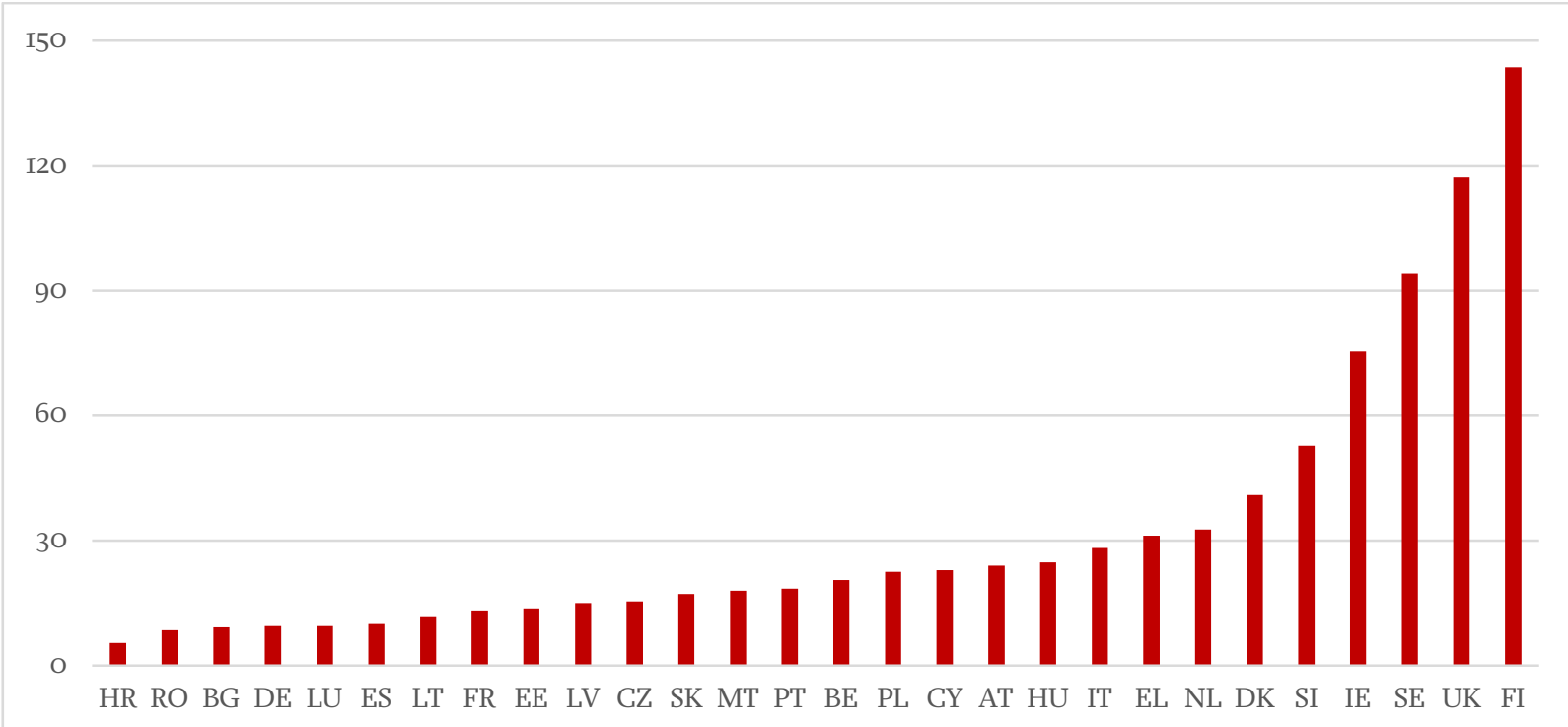

Note: AT-Austria, BE-Belgium, BG-Bulgaria, CY-Cyprus, CZ-Czech R, DE-Germany, DK-Denmark, EE-Estonia, EL-Greece, ES-Spain, FI-Finland, FR-France, HU-Hungary, IE-Ireland, IT-Italy, LT-Lithuania, LU-Luxembourg, LV-Latvia, MT-Malta, NL-Netherlands, PLPoland, PT-Portugal, RO-Romania, SE-Sweden, SI-Slovenia, SK-Slovakia, UK-United Kingdom.

Source: The Brewers of Europe (2012); Zakon o trošarinama.

The EU prescribes standard and reduced rates on wines. Most countries apply a standard zero rate to wine and in a lesser extent to sparkling wine. Most countries of the EU have decided on the application of a zero rate to still wines ${ }^{2}$, but in countries in which there is a high tax burden on alcohol (Sweden, Finland, Ireland and the UK) the rates vary from 200 to over 500 euro/hl.

In comparison with EU countries, the rate on ethyl alcohol in the Republic of Croatia (7I3 euro/hl) is among the lowest, matched only by Bulgaria (562 euro/hl). The highest rates are levied in Sweden (5,950 euro/hl), Finland (4,340 euro/hl) and the UK (3,36o euro/hl). A reduced rate on ethyl alcohol in the EU is applied to low strength spirits and in particular regions and for small distilleries the annual production of which comes up to Io hl of pure alcohol. Small producers of spirits in Croatia are those that produce up to 20 litres pure alcohol per household for personal use. The tax is charged according to the capacity of the still (IOo litres - Ioo kuna, greater than Ioo litres - 200 kuna). If they produce a greater quantity of spirits, an excise rate of 5,300 kuna/hl of pure alcohol is charged, as for all others liable to pay the tax.

\section{EXGISE DUTIES ON TOBACGO AND TOBACGO PRODUGTS}

The new Law harmonises the definitions of tobacco products and the amounts of excises on cigarettes. For the calculations of specific excises, the definition of a cigarette ${ }^{3}$ and the procedures for determining and reporting retail prices of tobacco products will be changed and the amount of excise duty on cigars and cigarillos will be equalised.

In accordance with the Directives (2010/I2/EU, 20II/64/EU and 20IO/I2/EU), instead of a retail price for the most popular price category of cigarettes (MPPC), the weighted average price (WAP) of

\footnotetext{
${ }^{2}$ Austria, Bulgaria, Cyprus, Czech R, Greece, Germany, Italy, Luxembourg, Hungary, Malta, Portugal, Romania, Slovenia, Slovakia and Spain.

${ }^{3}$ In the calculation of the specific excise, a cigarette is deemed to be a role of tobacco the length of which exclusive of tip or filter is up to $8 \mathrm{~cm}$, which is a change from the previously prescribed up to $9 \mathrm{~cm}$. Two cigarettes will be deemed to be constituted by cigarettes from 8 to $\mathrm{II} \mathrm{cm}$, and three from II to $\mathrm{I} 4 \mathrm{~cm}$, i.e. every additional $3 \mathrm{~cm}$ of length of a roll of tobacco without a filter will represent an increase of one cigarette.
} 
cigarettes released for consumption will be introduced as reference value and base for measuring the percentage of the share of a specific excise in the total tax burden. ${ }^{4}$

\section{Graph 2}

Rates of excise duties on cigarettes in EU countries (January I, 20I3) in euro, in \% of the weighted average retail price of cigarettes (WAP)

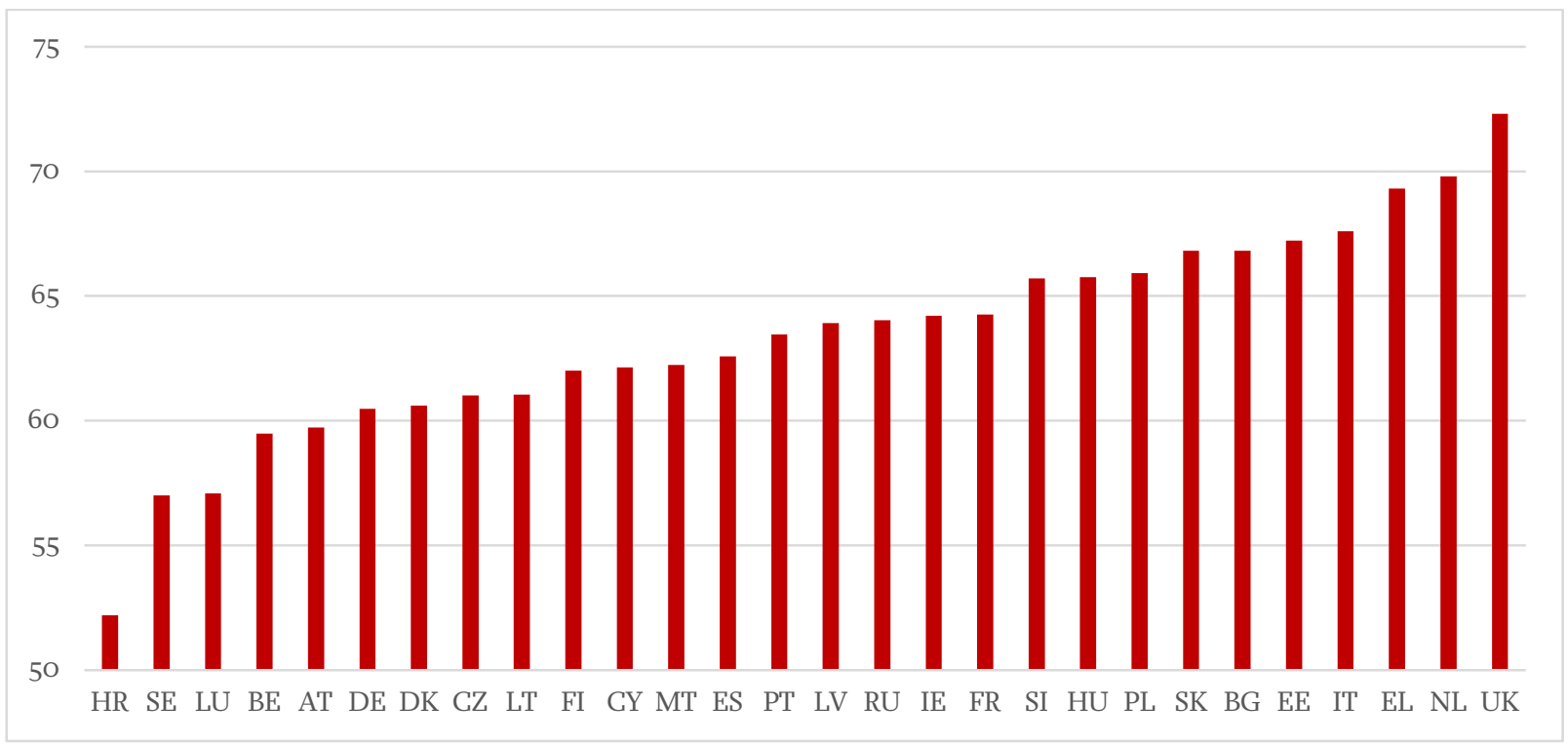

Note: The Croatian rate refers to the first II months of 2012.

Source: European Commission (2013c).

Graph 2 shows that the rate in Croatia is the lowest, and a long period of time will be needed for harmonisation with European rates. During the accession negotiations Croatia was given a transitional period up to December 3I, 2OI7, to achieve the minimal amounts of excise on tobacco, by which time gradual harmonisation has to be carried out in at least three phases. Harmonisation of the rates of excises on cigarettes was started in recent years, and the obligations for the future are as follows:

- July I, 2013 - total excise must come to at least $57 \%$ of the average weighted retail price of cigarettes released for consumption and 64 euro per I,Ooo cigarettes. Now it comes to $52.2 \%$ and 62.25 euro per I,OOO cigarettes (date for the first II months of 2OI2);

- January I, 2OI4 - at least 77 euro/I,OOO cigarettes, irrespective of WAP;

- December 3I, 2017 - 90 euro/I,Ooo cigarettes, in conjunction with a minimal $60 \%$ of the average weighted retail price of cigarettes released for consumption.

The directive prescribes equal minimal rates on cigars and cigarillos. On accession to the EU, the excise duty on cigars and cigarillos will come to 600 kuna/1,0oo cigars or cigarillos (8o euro/per I,Ooo items). Only Ireland (275 euro/I,Ooo items), the UK (243 euro/I,Ooo items), Estonia (2II/I,Ooo items) and Cyprus (9o euro/I,Ooo items) have a higher rate of specific excise on cigars.

On accession to the EU the excise on fine cut tobacco will increase, and the rise will continue in the following years. An almost 50\% rise in the rate is expected for other smoking tobacco, which is in line with EC recommendations so that for the sake of competition among tobacco products, particularly among cigarettes and other kinds of tobacco for smoking (which are equally harmful) the tax burden (i.e. rates) need equalising as much as possible.

\footnotetext{
${ }^{4}$ This is calculated as a ratio of total value of all cigarettes released for consumption in 2012 and total quantity of all cigarettes released for consumption in 2012.
} 
Table 2

Rates of excise duties on tobacco products in the Republic of Croatia and in the EU

\begin{tabular}{|c|c|c|c|c|}
\hline $\begin{array}{l}\text { Excisable } \\
\text { product }\end{array}$ & $\begin{array}{l}\text { Amount of excise } \\
\text { duty in the RC }\end{array}$ & $\begin{array}{l}\text { Amount of excise duty } \\
\text { in the RC after } \\
\text { accession to the EU }\end{array}$ & $\begin{array}{l}\text { Minimum excise duty } \\
\text { in the EU }\end{array}$ & $\begin{array}{l}\text { Minimum excise } \\
\text { duty in the EU } \\
\text { expressed in kuna }\end{array}$ \\
\hline \multicolumn{5}{|l|}{ Cigarettes } \\
\hline Specific & I8o kuna/I,ooo items & $64 € / I, 000$ items & $\begin{array}{l}64 € / \mathrm{I}, \mathrm{OOO} \text { items } \\
\text { irrespective of the WAP } \\
\text { share of specific excise } \\
\text { in total tax burden }\end{array}$ & \\
\hline & & & $5-76.5 \%$ & $475 \mathrm{kuna} / \mathrm{I}, \mathrm{OoO}$ items \\
\hline & & & $\begin{array}{l}\text { - from January I, } 2014 \\
77 € / I, 000 \text { items } \\
\text { irrespective of WAP; }\end{array}$ & $572 \mathrm{kuna} / \mathrm{I}, \mathrm{Ooo}$ items \\
\hline & & & $\begin{array}{l}\text { - up to December 3I, } 20 I 7 . \\
\text { 9o euro/I,OOo items } \\
\text { irrespective of WAP; } \\
\text { share of specific excise } \\
\text { duty in total tax 7,5 - 76.5\%. }\end{array}$ & $668 \mathrm{kuna} / \mathrm{I}, \mathrm{Ooo}$ items \\
\hline $\begin{array}{l}\text { Ad valorem } \\
\text { excise in \% }\end{array}$ & $\begin{array}{l}36 \% \text { of retail selling } \\
\text { price (includ. all taxes) }\end{array}$ & $57 \%$ WAP & $\begin{array}{l}57 \% \text { share of total excise } \\
\text { in WAP; } \\
\text { - from January I, 2OI4. } \\
60 \% \text { share of total excise } \\
\text { in WAP; }\end{array}$ & \\
\hline \multicolumn{5}{|l|}{ Cigars } \\
\hline & I,IOO kuna/I,OOO items & $600 \mathrm{kuna} / \mathrm{I}, \mathrm{OoO}$ items & $\mathrm{I} 2 € / \mathrm{I}, \mathrm{OOO}$ items & $89 \mathrm{kuna} / \mathrm{I}, \mathrm{oOo}$ items \\
\hline \multicolumn{5}{|l|}{ Gigarillos } \\
\hline & 220 kuna/I,OOo items & $600 \mathrm{kuna} / \mathrm{I}, \mathrm{ooo}$ items & $\mathrm{I} 2 € / \mathrm{I}, \mathrm{OOO}$ items & $89 \mathrm{kuna} / \mathrm{I}, \mathrm{Ooo}$ items \\
\hline \multicolumn{5}{|l|}{$\begin{array}{l}\text { Fine cut } \\
\text { smoking } \\
\text { tobacco }\end{array}$} \\
\hline & $325 \mathrm{kuna} / \mathrm{kg}$ of product & $35 \mathrm{I} \mathrm{kuna} / \mathrm{kg}$ of product & $\begin{array}{l}\text { from January I, 20I3 - 47 } € / \mathrm{kg} \\
\text { from January I, 20I5 - } 54 € / \mathrm{kg} \\
\text { from January I, 20I8 - 6o } € / \mathrm{kg} \\
\text { from January I, 202O- } 60 € / \mathrm{kg} \\
\end{array}$ & $\begin{array}{l}349 \mathrm{kuna} / \mathrm{kg} \\
40 \mathrm{kuna} / \mathrm{kg} \\
446 \mathrm{kuna} / \mathrm{kg} \\
446 \mathrm{kuna} / \mathrm{kg}\end{array}$ \\
\hline \multicolumn{5}{|l|}{$\begin{array}{l}\text { Other } \\
\text { smoking } \\
\text { tobacco }\end{array}$} \\
\hline & I46 kuna/I,ooo items & $296 \mathrm{kuna} / \mathrm{I}, \mathrm{ooo}$ items & $22 € / \mathrm{kg}$ & I63 kuna/I,Ooo items \\
\hline
\end{tabular}

Source: European Commission (2013c); Zakon o trošarinama.

\section{EXGISE DUTIES ON ENERGY PRODUGTS AND ELEGTRIGITY}

The biggest changes in the system of exercise duties will relate to energy products and electricity. In addition to an increase of the rate, taxation will also be extended to natural gas, coal, coke and electricity. The system for taxing energy products in the EU is the most complex - according to the number of taxable products, the number and the amounts of the rates and the series of exemptions and particularities in given countries. Apart from harmonised excises on energy products, 8 countries $^{5}$ also introduced special parafiscal levies and charges for some kinds of energy products. Apart from fiscal reasons, there are ever more important ecological reasons for taxing energy products, which has affected the rise and increasing differentiation of the rates. All countries including Croatia - have in common the fact that it is precisely revenues from energy product excises that have the greatest share in the totally revenues of excises.

It can be seen from Table 3 that the rates are on the whole harmonised with the minimally prescribed rates, except that they are lower for LPG and natural gas that is used for propellant. The rates will be raised on gas oil for propellant use (4\%) and on kerosene - paraffin (9\%). But it also should not be forgotten that from January I, 2013 by the Regulation (OG I44/I2) - along with other things - these excises are increased (by $15 \%$ and $2 \%$ ). Although in the EU the minimally prescribed excise duty on kerosene meant for heating has a rate of $0 \%$, the new Law has introduced a taxation of 1,752 kuna/I,Ooo l. The greatest change relates to the introduction of taxation of natural gas, coal, coke and

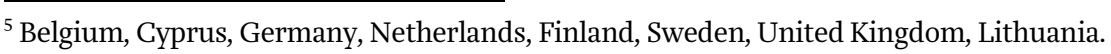


electricity, the rates of which are on the whole at the level of the minimum, and are higher on natural gas meant for heating. In the Law certain exemptions are prescribed for the use of energy products and electricity for given purposes. The most important relate to natural gas and electricity used in households and gas used as propellant.

Article IOI regulates exemptions related to:

- the use of natural gas and electricity in some industrial processes and on the electricity obtained from renewable energy sources (if the producer uses it for its own needs);

- energy products that are used as propellant for navigation, including fishing and electrical energy produced on a vessel (apart from the use of vessels and floating vessels for private purposes);

- $\quad$ energy products that are used as aviation fuel (except for use for private flights).

Table 3

Rates of excise duties on energy products and electricity in the Republic of Croatia and in the EU

\begin{tabular}{|c|c|c|c|c|}
\hline Excise product & $\begin{array}{l}\text { Amount of excise } \\
\text { duty in RC }\end{array}$ & $\begin{array}{l}\text { Amount of excise } \\
\text { duty in RG after EU } \\
\text { accession }\end{array}$ & $\begin{array}{l}\text { Minimum excise } \\
\text { duty in the EU } \\
\text { (in euro) }\end{array}$ & $\begin{array}{l}\text { Minimum EU } \\
\text { excise duty } \\
\text { expressed } \\
\text { (in kuna) }\end{array}$ \\
\hline \multicolumn{5}{|l|}{ Petrol } \\
\hline leaded & 3,80I kuna/I.oool & & $42 \mathrm{I} € / \mathrm{I}, \mathrm{OOOO} \mathrm{l}$ & 3,I26 kuna/I,Ooo l \\
\hline unleaded & 3,I5I kuna/I.ooo l & & $359 € / \mathrm{I}, \mathrm{OOO} \mathrm{l}$ & 2,666 kuna/I,ooo l \\
\hline \multicolumn{5}{|l|}{ Gas oil (diesel) } \\
\hline motor fuel & 2,354 kuna /I.oool & \multirow[t]{3}{*}{2.450 .50 kuna/ I,OOo l } & $330 € / \mathrm{I}, \mathrm{OOO} \mathrm{l}$ & $2,450 \mathrm{kuna} / \mathrm{I}, \mathrm{OOO} \mathrm{l}$ \\
\hline heating & 343 kuna/I.oool & & $2 \mathrm{I} € / \mathrm{I}, \mathrm{OOO} \mathrm{l}$ & I56 kuna/I,ooo l \\
\hline industrial and commercial use* & & & $2 \mathrm{I} € / \mathrm{I}, \mathrm{OOO} \mathrm{l}$ & I56 kuna/I,ooo l \\
\hline \multicolumn{5}{|l|}{ Kerosene - paraffin } \\
\hline for motors & 2,243 kuna/I.ooo l & \multirow{3}{*}{$\begin{array}{l}2.450 .50 \text { kuna I,OoO l } \\
\text { I. } 752 \text { kuna/I,ooo l }\end{array}$} & $330 € / \mathrm{I}, \mathrm{OOO} \mathrm{l}$ & $2.450 \mathrm{kuna} / \mathrm{I}, \mathrm{OOO} \mathrm{l}$ \\
\hline for heating & & & $\mathrm{o} € / \mathrm{I}, \mathrm{OOO} \mathrm{l}$ & o kuna \\
\hline industrial and commercial use & & & $2 \mathrm{I} € / \mathrm{I}, \mathrm{OOO} \mathrm{l}$ & I56 kuna/I,ooo l \\
\hline \multicolumn{5}{|l|}{ LPG - Liquefied petroleum gas } \\
\hline for motors & 9I2.50 kuna/I.00o kg & IOo kuna/I,OOo kg & $\mathrm{I} 25 € / \mathrm{I}, \mathrm{OOO} \mathrm{kg}$ & $928 \mathrm{kuna} / \mathrm{I}, \mathrm{OOO} \mathrm{kg}$ \\
\hline $\begin{array}{l}\text { for heating (business/non- } \\
\text { business) }\end{array}$ & o kuna/I.ooo kg & Ioo kuna/I,OOo kg & & o kuna \\
\hline industrial and commercial use & & & $4 \mathrm{I} € / \mathrm{I}, \mathrm{OOO} \mathrm{kg}$ & $304 \mathrm{kuna} / \mathrm{I}, \mathrm{Ooo} \mathrm{kg}$ \\
\hline \multicolumn{5}{|l|}{ Heavy heating oil } \\
\hline business & I6o kuna/I.00o kg ${ }^{6}$ & \multirow[b]{3}{*}{ o kuna } & $\mathrm{I} 5 € / \mathrm{I}, \mathrm{OOO} \mathrm{kg}$ & \multirow{3}{*}{$\begin{array}{l}\text { III kuna/I,OOO kg } \\
\text { III kuna/I,OOo kg }\end{array}$} \\
\hline non-business & & & I5 $€ / \mathrm{I}, \mathrm{OOO} \mathrm{kg}$ & \\
\hline biofuel - pure & & & - & \\
\hline \multicolumn{5}{|l|}{ Natural gas } \\
\hline for motors & & o kuna/MWh & $2.6 € / G \mathrm{~J}$ & I9 kuna/GJ \\
\hline for heating - non-business & & $\begin{array}{l}\text { 8.Io kuna/MWh }{ }^{7} \\
(29.6 \mathrm{kuna} / \mathrm{GJ})\end{array}$ & $0.3 € / \mathrm{GJ}$ & $2.23 \mathrm{kuna} / \mathrm{GJ}$ \\
\hline for heating - business use & & $\begin{array}{l}4.05 \mathrm{kuna} / \mathrm{MWh} \\
\text { (I4.6 kuna/GJ) }\end{array}$ & O.I5 $€ / G J$ & I.II kuna/GJ \\
\hline industrial and commercial use & & & $0.3 € / \mathrm{GJ}$ & $2.23 \mathrm{kuna} / \mathrm{GJ}$ \\
\hline \multicolumn{5}{|l|}{ Coal and coke } \\
\hline non-business use & & $2.30 \mathrm{kuna} / \mathrm{GJ}$ & $0.3 € / \mathrm{GJ}$ & $2.23 \mathrm{kuna} / \mathrm{GJ}$ \\
\hline business use & & 2.30 kuna/GJ & $0.15 € / G J$ & I.II kuna/GJ \\
\hline \multicolumn{5}{|l|}{ Electricity } \\
\hline non-business use & & 7.50 kuna/MWh & $\mathrm{I} € / \mathrm{MWh}$ & 7.43 kuna/MWh \\
\hline business use & & 3.75 kuna/MWh & O.5 EUR/MWh & 3.7I kuna/MWh \\
\hline
\end{tabular}

*Except for agriculture.

Source: European Commission (2013b); Zakon o trošarinama.

Existing exemptions for diesel will still be applied (blue diesel) meant for farming, fishing and in fish farming, along with the introduction of exemptions on marked gas oil for motor fuel in national commercial voyages on international lines, domestic waters and within a MS.

\footnotetext{
${ }^{6}$ Although products in terms of the Combined Nomenclature are the same as in the Directive, ZOT does not say whether the heating is for business or non-business purposes.

${ }^{7}$ Converted I MWh $=3.6 \mathrm{GJ}$.
} 
Graph 3

Maximum excises on petrol (leaded and unleaded) in EU countries ( $€ / \mathrm{I}, \mathrm{Ooo} l)$

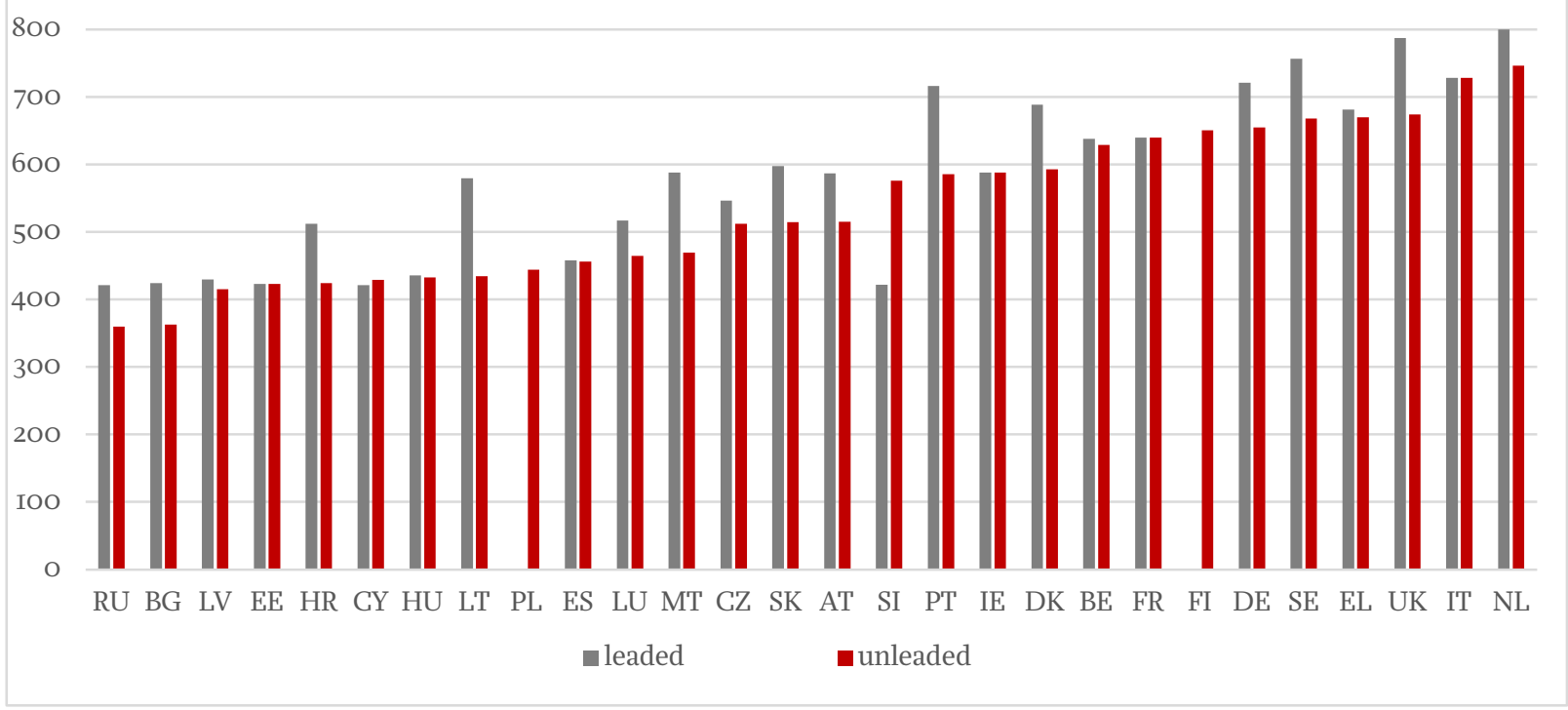

Source: European Commission (2013b); Zakon o trošarinama.

Graph 3 displays the maximum excises for leaded and unleaded petrol. In European countries, different rates are applied o the same product depending on the contents of sulphur, $\mathrm{CO}$, biofuel and on the purpose or the region for which the fuel is used. In Poland, Slovenia and Finland, the use of leaded petrol is banned. Four EU countries have rates on leaded petrol that are lower than the Croatian, the highest rates being in the Netherlands, the UK and Sweden. In the Republic of Croatia gas oil (diesel fuel) for motors will be taxed at the minim rate of 330 euro/I,Ooo l, which is the lowest in the EU. Some counters, like the Republic of Croatia, have used the possibility of applying a reduced rate for diesel fuel that is used in some sectors (agriculture, fishery, horticulture, forestry, railway transport). The rate of excise duty on kerosene used as a motor fuel will be equalised with the minimum (330 euro/I,Ooo l) and the taxation of kerosene used for heating will be introduced (I,752 kuna/I,Ooo l) as well as on LPG for heating. Although the Directive envisages a zero rate for kerosene and LPG meant for heating, almost all of the EU countries actually tax these products. The minimal rate on natural gas that is used as motor fuel is 2.6 euro/GJ. In the new Law, this rate is not harmonised with the Directive, i.e. it comes to o kuna/MWh, which is not equally to the exemption in Article IOI.(8). The minimal rate in EU countries on gas for heating (business use) comes to 0.I5 euro/GJ and ranges from o to 9.37 euro/GJ. The minimum rate for business use of electricity comes to 0.5 euro/MWh, and for non-business use I euro/MWh. The rates are the highest in the Netherlands (II6 euro/MWh) and Denmark (94-Ioo euro/MWh). On accession to the EU, Croatia will have rates equal to the minimum. In the taxation of electricity too there is the chance of applying reduced rates for given sectors.

\section{CONCLUSION}

Although in the new Law on Excises the rates of excise duties are by and large harmonised with the minimal rates prescribed in the Directives, in the future we will be greeted with a further rise in the rates (on cigarettes and fine cut tobacco for smoking). Apart from a general (single) rate that is applied to excise products in Croatia and the EU there are differences in the number of rates, and under certain conditions reduced rates will be applied to the same products. In the taxation of energy products the lower rates on LPG and natural gas for motor fuel are not harmonised. Directive 2003/96/EU prescribes that energy products (gas oil - diesel, kerosene - paraffin, LPG and natural gas) meant for industrial and commercial use are taxed, which the new Law on Excises has not yet enjoined.

However, if the condition of minimal rates prescribed by EU Directives is achieved, the Government of the Republic of Croatia can, according to the Law on Excises (Article 6o Item 7) issue an order 
changing (increasing) the prescribed rates of excises. Depending on the objectives and the needs of fiscal policy (shortfall of budgetary revenues, rise in public expenditure, rise in the public debt and so on) the rates may be changed. Each increase in a tax affects the price of the taxable products and hence it can be expected that there will be a rise in the price of cigarettes, other tobacco and energy products. The rise in the price of cigarettes is not very alarming, but the rise in the price of energy products, notwithstanding certain exemptions, will conduce considerably to a general price rise and affect the living standards of citizens and the operations of the business sector

According to the outline estimate of the Ministry of Finance, the introduction of excise duties on electricity should lead to an increase in retail price of $1.05 \%$, of natural gas of $3.41 \%$ (end users connected to the transport system) or by $2.38 \%$ to end users connected to the distribution system.

When there is discussion of the impact on prices, one should bear in mind not only excises but also VAT, which is calculated on the retail price. The rate of VAT in the Republic of Croatia is one of the highest in the EU and, which is more important still, higher than the rate in neighbouring countries (save for Hungary). In spite of lower excises, the prices of excisable products in the Republic of Croatia might be higher, which would encourage legal as well as illegal cross-border purchasing, and thus lead to a reduction of tax revenues. The new Law on Excises also includes new and more detailed provisions about the conduct of supervision (more effective legal framework for suppressing, preventing and penalising illegalities and tax evasion) and more comprehensive measures and activities preventing offences and punishing offenders. However, legal cross-border purchase of products cheaper in neighbouring countries can still have an effect on tax revenues.

\section{REFERENCES}

Council Directive 2003/96/EC of 27 October 2003 restructuring the Community framework for the taxation of energy products and electricity.

Council Directive 20I0/I2/EU of I6 February 2010 amending Directives 92/79/EEC, 92/80/EEC and 95/59/EC on the structure and rates of excise duty applied on manufactured tobacco and Directive 2008/II8/EC.

Council Directive 20II/64/EU of 2I June $201 \mathrm{I}$ on the structure and rates of excise duty applied to manufactured tobacco.

Council Directive 92/84/EEC of 19 October 1992 on the approximation of the rates of excise duty on alcohol and alcoholic beverages.

European Commission, 20I3a. Excise Duty Tables Part I - Alcoholic Beverages [online]. Available at <http://ec.europa.eu/taxation_customs/resources/documents/taxation/excise_duties/alcoholic_ beverages/rates/excise_duties-part_i_alcohol_en.pdf>.

European Commission, 20I3b. Excise Duty Tables Part II - Energy products and Electricity [online]. Available at: <http://ec.europa.eu/taxation_customs/resources/documents/taxation/ excise_duties/energy_products/rates/excise_duties-part_ii_energy_products_en.pdf $>$.

European Commission, 20I3c. Excise Duty Tables Part III - Manufactured Tobacco [online]. Available at: <http://ec.europa.eu/taxation_customs/resources/documents/taxation/excise_duties/ tobacco_products/rates/excise_duties-part_iii_tobacco_en.pdf>.

The Brewers of Europe, 2012. Excise Duty Rates for Beer in Europe [online]. Brussels: The Brewers of

Europe. Available at: 〈http://www.brewersofeurope.org/docs/ publications/BED2OI2.pdf〉.

Uredba o visini trošarine na motorne benzine, plinsko ulje i kerozin za pogon, NN I44/I2. Zagreb: Narodne novine.

Zakon o trošarinama, NN 83/o9, 3/I2, 22/13. Zagreb: Narodne novine. 